\title{
The COMmon GoOd In AN AgE OF MORAL HYPERPLURALISM: A CATHOLic Bioethical Perspective
}

\author{
John Kleinsman*
}

\begin{abstract}
This article will argue that the notion of the common good is imperilled by a particular contemporary account of the moral good; one which, because of its (somewhat narrow) emphasis on the individual, readily lends itself to a state of 'moral hyperpluralism' in which 'the good' is primarily defined in terms of the promotion and protection of self-interest. At the same time, it will be argued that any quest to recover the notion of the common good cannot be achieved by either returning to, or holding onto, a more traditional account of morality. It will also be proposed that, as part of the quest to recover the common good, close attention needs to be paid to how the term is understood. The tension between individual autonomy and the welfare of society, and the differing ways in which this tension is resolved within different moral paradigms, will emerge as central to any discussion about the ongoing place of the common good in contemporary legal and moral debates. Finally, it is suggested that a solid basis for articulating a robust account of the common good may be found in the foundational and innovative work being done by thinkers of the gift to establish an alternative account of morality.
\end{abstract}

\section{INTRODUCTION}

The Constitution on the Church in the Modern World, a document produced by the Second Vatican Council and promulgated in 1965, speaks to Catholics of the need to scrutinise and interpret "the signs of the times" and to respond to them by entering into honest and sincere dialogue. ${ }^{1}$ The implications for theology, and in particular for moral theology, are clear; theologians and ethicists must engage with people's issues and questions and be attentive to the societal context in which we live. Consequently, a key section of this article will be given over to describing the moral context in which we find ourselves reflecting on the common good.

* PhD. Director of The Nathaniel Centre - the New Zealand Catholic Bioethics Centre.

1 Second Vatican Council "Pastoral Constitution on the Church in the Modern World - Gaudium et Spes" in A Flannery (ed) Vatican Council II: The Conciliar and Post Conciliar Documents (The Liturgical Press, Indiana, 1965) 4 at 905. 
The notion of the common good provides for a rich discussion. A comprehensive ethical exploration of the common good should take account of both the global and the ecological implications of the notion. The fact that this article takes a narrower moral perspective, which does not directly address either of these areas, is not to dismiss their importance. It also needs to be acknowledged from the start that the focus and findings of this article reflect both the strengths and weaknesses of my own partial perspective - that of a male Catholic whose academic formation has most recently been both shaped and limited by my full-time involvement in bioethical research.

The title of the conference, "Recovering the Common Good", assumes that the notion of the common good, one that originated over two thousand years ago in the writings of Plato, Aristotle and Cicero, is in need of recovery. ${ }^{2}$ This immediately gives rise to a number of questions. If our aim is to recover the common good, does that mean it has been lost and needs to be found and reinstated? Or might it be that the debate is actually about the adequacy of a particular contemporary understanding and expression of the common good that gives exaggerated priority to an individual's right to choose? In which case we might decide that the urgent task is to find and embrace a different understanding of the common good - either a return to a previous understanding or an alternative understanding that speaks to the post-modern age in which we find ourselves. Behind these questions lies a further question, is the notion of the common good a static one that provides a clear and unwavering point of reference or one that is itself subject to evolution and change?

In exploring these questions this article will argue that the notion of the common good is imperilled by a particular contemporary account of the moral good. Further, it will be argued that any quest to recover the notion of the common good cannot be achieved by either returning to, or holding onto, a more traditional account of morality. It will also be proposed that, as part of the quest to recover the common good, close attention needs to be paid to how the term is understood, while concluding that the understanding of the common good has itself evolved in Catholic moral teaching since the Second Vatican Council (1962 to 1965). It is taken as read that the Catholic moral and social tradition remains a key voice in any contemporary conversation about the common good given what Velasquez and others describe as the Catholic tradition's "long history of struggling to define and promote the common good..."3

While the question of how exactly we are to understand the notion of the common good will emerge as part of the argument to be developed, a basic definition is required. ${ }^{4}$ For the purposes of establishing a point of departure, I take the term to mean that the good of each and every person is inextricably bound up with the good of the community. That is to say, the common good is

2 Manuel Velasquez and others "The Common Good" (1992) 5 Issues in Ethics $<$ www.scu.edu/ethics/practicing/decision/commongood.html $>$.

3 Velasquez and others, above n 2.

4 For other definitions see articles by Beech and Bradstock in this issue. 
understood as that concept which somehow regulates the reciprocal relationship between the person and society. The tension between individual autonomy and the welfare of society, and the differing ways in which this tension is resolved within different moral paradigms, will emerge as central to any discussion about the ongoing place of the common good in contemporary debates.

An interest in the potential of the common good to usefully inform emerging and urgent bioethical questions, generated by recent technological developments, forms part of the backdrop of this article. To that end, a number of examples from the field of bioethics will be used to illustrate and ground the various points that are developed. In line with the earlier stated purpose of describing the contemporary moral context or moralscape in which we find ourselves pondering the common good, the article will begin with an overview of two different, and in many ways conflicting, moral accounts that characterise contemporary moral deliberation. These two accounts, it should be noted, are offered as broad categories, rather than specific moral theories, that encompass a range of different, although broadly related, approaches to moral decision making.

\section{II "TRADITIONAL" MORALITY}

Catholic bioethicist Kevin McGovern, one of many commentators to have analysed the contemporary moralscape, concludes that it is defined by a clash within our civilisation. McGovern describes this clash as being between a traditional morality and a new or emerging morality, which goes back to the 18 th century. ${ }^{5}$ His analysis is useful for informing deliberations on the common good.

McGovern begins by observing that there are striking similarities between multiple accounts of the traditional morality that define different eras. He also observes that the similarities extend to different cultures and civilisations. We should not be surprised by this, he adds, given that one of the tasks of morality is to set out the attitudes and behaviours that truly promote human flourishing. ${ }^{6}$ After noting that within Western civilisation the traditional account of morality has its origins in two sources, the Judaeo-Christian ethic and Greco-Roman philosophy, McGovern then postulates that it can be understood in terms of four key themes. ${ }^{7}$

First, traditional morality accepts that life is precarious and that we must continue to work to build the common life of society as well as individual life. Secondly, McGovern notes that traditional morality is based on a common understanding of what it is to be human. Thirdly, he argues that traditional morality is underpinned by the idea that human beings find their fulfilment above all through service. McGovern finds that: ${ }^{8}$

\footnotetext{
$5 \quad$ K McGovern "Remaining True" (2011) 17 Chisholm Health Ethics Bulletin.

6 McGovern, above $\mathrm{n} 5$, at 1

7 At 2

8 At 2 .
} 
we are happiest and most fulfilled not when we are overly focussed on ourselves and our rights and needs and our wants, but rather when we give ourselves away in service.

Fourthly, he notes that traditional morality is specifically concerned with integrating three distinct but interrelated perspectives: the common good of society, the good of families and the good of individual persons.

McGovern concludes that the perennial challenge for traditional morality is to hold all of these perspectives in the right balance. Nevertheless, within this balance, he understands that the focus is above all on, a particular understanding of, the common good. ${ }^{9}$ This concept is, he argues, "the most distinctive feature of traditional morality", its leitmotif or central idea. ${ }^{10}$ Noting that traditional morality often asks us to make some individual sacrifice for the good of all, McGovern postulates that the need to sacrifice the self may be one reason why many people today reject traditional morality. The same point is echoed by many others, including Newsweek business and economic journalist and columnist Robert J Samuelson who has written: "We face a choice between a society where people accept modest sacrifices for a common good or a more contentious society where groups selfishly protect their own benefits." ${ }^{11}$

The close connection between the common good and the virtues of service and self-sacrifice needs little explaining. A broad-based commitment to the common unity shared by all persons implies an ability to look beyond the self; an ability to eschew an individualistic perspective in the interests of, those who are in need, especially, when that calls for the priority of the other over oneself. In other words, the traditional account of morality promotes a perspective which prioritises consideration of the broader social and relational dimensions in discussions about the place of individual autonomy in morality, ethics and law - something that is unquestionably critical to the notion of the common good.

Among those who have not rejected the traditional account and who seek to uphold it in the current age the Churches are at the fore. Evidence of this may be found in the way arguments about particular bioethical issues are framed, including: the appeal to service, sacrifice and communal values.

For example, in a recent statement on the dangers of euthanasia issued by the New Zealand Catholic Bishops in 2011, ${ }^{12}$ they begin by asking a question which invites deeper reflection about

9 This article will investigate whether the understanding of the common good which is upheld in those approaches to moral decision making that fall under the broad classification of the traditional account may, ultimately, be found wanting in some key way.

10 McGovern, above n 5, at 2.

11 Cited in Velasquez and others, above $\mathrm{n} 2$.

12 The use of euthanasia as an example is for illustrative purposes only. It is used to help explain the typical approach taken by those who draw on a traditional approach to morality or ethics. It is beyond the scope of 
the social order of which we are all a part: "What kind of society would we have if euthanasia were legalised?"13 The arguments offered by the Bishops against a law change draw on the idea that "legalising euthanasia will place at greater risk the lives of those whom others might be tempted to think would be better off dead." 14 Noting that "persistent requests for euthanasia are not related to physical pain but to depression and feelings of hopelessness and/or a sense of social isolation" 15 they conclude that both the problem and solution lie within society: ${ }^{16}$

... we cannot be free from blame if there are people in our communities unable to find human comfort and assistance as they approach the end of their lives. The real moral imperative is on us all to be bearers of hope and to offer selfless care to all those who are sick, disabled and dying.

Finally they conclude, the introduction of euthanasia or assisted-suicide: ${ }^{17}$

would seriously undermine good caring and be detrimental to the growth of a caring community ... The mark of a great society is evidenced in its ability to care for those who are most vulnerable

In a similar vein, David Brooks, an op-ed columnist for the New York Times, also articulates a number of the key traits of traditional morality in his discussion of "The Age of Possibility" ${ }^{18}$ and thereby identifies himself as committed to a version of the traditional account. Defining the age of possibility as that in which people are "intolerant of any arrangement that might close off their personal options" he then concludes: ${ }^{19}$

My view is that the age of possibility is based on a misconception. People are not better off when they are given maximum personal freedom to do what they want. They're better off when they are enshrouded in commitments that transcend personal choice - commitments to family, God, craft and country. The surest way people bind themselves is through the family. As a practical matter, the traditional family is an effective way to induce people to care about others, become active in their communities and devote themselves to the long-term future of their nation and their kind.

this article to offer a critical or substantive analysis of the arguments associated with the legalisation of euthanasia.

13 New Zealand Catholic Bishops' Conference "The Dangers of Euthanasia: A Statement from the New Zealand Catholic Bishops" (19 October 2011) The Catholic Church in Aoteraroa New Zealand $<$ www.catholic.org.nz/nzcbc/>.

14 New Zealand Catholic Bishops' Conference, above n 13.

15 New Zealand Catholic Bishops' Conference, above n 13.

16 New Zealand Catholic Bishops' Conference, above n 13.

17 New Zealand Catholic Bishops' Conference, above n 13.

18 David Brooks "The Age of Possibility" The New York Times (online ed, New York, 15 November 2012).

19 Brooks, above n 18. 
The clearly expressed idea that human flourishing, and in particular the fulfilment of individuals, is inextricably tied up with the well-being of the communities is distinctive of traditional accounts of morality.

The traditional account is particularly attentive to the perspectives of society and the family in its approach to issues such as euthanasia and these constitute an essential component of the notion of the common good. The next task is to examine new morality in order to evaluate its compatibility with the same notion.

\section{NEW MORALITY}

McGovern defines new morality as underpinned by an Enlightenment assumption that there is no common understanding of what it is to be human: ${ }^{20}$

There is only my view and your view and everyone else's view, and the Enlightenment assumes both that these are all very different and that we have no way of deciding which ones are better and more accurate than some of the others.

In other words, the vision offered by this account "is that as much as possible each of us should be free to follow our own path and pursue our own goals and live our own way." ${ }^{21}$ In contrast to the traditional account, that rather than finding fulfilment through service, it is to be found through free choice - a very different vision for human fulfilment and a very different way of resolving the tension that exists between the well-being of the individual and that of the community. McGovern then concludes that the leitmotif or central idea of the new morality is free choice.

McGovern sees the Enlightenment vision carried to its extreme in the Baby Boomers generation born between 1946 and 1964 (and inherited by Generation X, Generation Y and Generation Z who have learnt from their Baby Boomer parents and grandparents): ${ }^{22}$

We are the 'me' generation ... We rail and fight against anything that would restrict our free choice. We are the generation which effectively decriminalised abortion in many jurisdictions around the world; we are the generation which is currently most passionately involved in the battle to legalise euthanasia.

At the same time, McGovern points out that the new morality in western society has evolved in a context characterised by the development of secularisation which he describes as the eclipse for many of a sense of God. Losing sight of the spiritual side of life, he notes, means that we have come to focus more on the material side. This has, in turn, led to a new emerging virtue, consumption, built on the idea that the path to human fulfilment lies with consuming and getting what we want.

20 McGovern, above n 5.

21 McGovern, above n 5.

22 At 3. 
As much as the traditional account naturally lends itself to a perspective characterised by a concern for the needs and well-being of the wider human community, the new account of morality, focused as it is on the rights, freedom, uniqueness and autonomy of the individual, naturally inclines us away from considerations of communal well-being. In line with the moral axiom that paradigms teach us to notice certain things and not to notice certain things, it might be said that the new account teaches us not to notice or focus on those questions related to communal consequences. The result of exalting the isolated individual as the primary locus for moral deliberation means there is reduced space in ethical and moral deliberations for notions such as solidarity, service to others and self-sacrifice. These considerations are discounted in favour of concerns consistent with a more individualistic concept of human flourishing.

Proponents of the new account of morality may recognise that the description of this account offered above fits neatly with the ideology that underpins neo-liberal theories of politics and economics. Consequently, in response to the argument that an emphasis on the individual naturally inclines persons away from communal considerations, they might point out that their framework embodies an alternative approach to collective well-being; that the privileging of self-interest ultimately contributes to the betterment of the community by way of regulatory mechanisms inherent in the make-up of the market place. In other words, the direct promotion of what is good for the individual ultimately benefits society as a whole. This point deserves consideration.

First, it needs to be noted that such an analysis fails to adequately account for the philosophical differences that distinguish the common good, properly understood, from other actions which lead to an overall increase in betterment when aggregated across society as a whole. Without this distinction, utilitarianism, which is about ensuring the greatest good for the greatest number of people, would arguably qualify as an expression of the common good. In fact, recalling that the common good involves regulating the reciprocal relationship between the person and society (see the definition offered in the introductory comments above), utilitarianism is rightly judged to be the antithesis of the common good because it allows for the rights and well-being of particular individuals to be completely over-ridden by what is deemed good for the majority. ${ }^{23}$

Secondly, even setting aside the coherence and robustness of the neo-liberal approach and its assumptions about human flourishing (which goes beyond the scope of this article), it cannot be denied that from the point of view of intention - which is critical for assessing actions from a moral/ethical perspective - the new and traditional accounts of morality are sharply divided. Accepting that the former account focusses on the promotion of self-interest, while the latter assumes a broader and more inclusive perspective, which focuses on the requirements of those 'others' with whom we exist in relationships of interdependence, collective well-being is, at best, an accidental by-product of the new account. Conversely, within the traditional account, it forms an

23 See also the Beech article in this issue. 
integral part of a person's fundamental option for life, evidence for which is readily apparent in the reasoning that underpins the specific decisions and actions of persons operating within the various moral theories, which this account encompasses.

Once again the debate about euthanasia is enlightening. Even a cursory review of the main arguments appealed to by those who favour the legalisation of euthanasia and/or assisted-suicide highlights the priority of the individual and the predominance of individual choice, individual rights and self-determination over collective well-being. Unlike traditional morality, which reserves a place for the individual while seeking to balance it with what is best for society as a whole, it is characteristic of the new morality that an individual's right to choose by and large occurs at the expense of any assessment of the effects of such decisions on society. Granted, many versions of the new morality accept that a person's choices may be limited (by the appropriate authorities) to the extent they cause harm to others. Increasingly, however, this harm is narrowly measured in terms of the negative impact a person's choices might have on the rights of others to exercise their own personal autonomy.

The claim of the new morality is accurately represented by the oft-heard phrase, "my body, my choice." Daniel Callahan, describing the case in favour of assisted-suicide, puts it well, if nature is no longer able to perfectly assure us of a peaceful death, then "we must shape, by our choice, a death of our own making." 24

Blogger David is an ardent disciple for the cause. Commenting on the self-inflicted deaths of a Wellington couple in 2012 he writes: ${ }^{25}$

SO WHAT if others were shocked to find they ended their own lives, GET OVER IT, it was their life NOT Yours or anyone else's. The RIGHT to die should reside with the Person who wishes to Die and NO ONE ELSE, Especially not the Government ... Let people Die if they are Terminally Ill, and let their Life Long companions join them if they so wish ... Maybe our Law makers and any opposition to the RIGHT TO DIE, should sit through a few dozen dying peoples lasts weeks ... [sic]

Interestingly, from a strictly utilitarian perspective, various commentators have postulated that there is the potential for society, or more specifically the state, to benefit financially from legalising euthanasia and/or assisted-suicide. Taking into account the ever increasing scarcity of healthcare resources as well as the rising number of elderly persons and a shrinking tax base, it would be naïve to believe that financial considerations would not impact on people's thinking in a context in which

24 D Callahan "Reason, Self-Determination and Physician-Assisted Suicide" in K Foley and H Hendin (ed) The Case against Assisted Suicide: For the Right to End-of-Life Care (Johns Hopkins University Press, Baltimore, 2002) at 53 .

25 Rosemary Mcleod "Wanting Help to Die is not the Government's Business" The Press (online ed, Christchurch, 3 March 2012). This comment to the online version of the article has since been removed from the website. A copy is available from the author. 
life is increasingly being viewed through an economic lens. Therefore, there exists an undeniable opportunity for the not-inconsiderable expenses associated with ongoing medical treatment and care at the end of life to be reduced. ${ }^{26}$ When this benefit is placed alongside the claimed benefits of assisted suicide or euthanasia for individuals, namely the opportunity to alleviate personal suffering through a premature death, a degree of synchronicity becomes evident between the promotion of self-interest and societal benefits.

However, if it is accepted that legalising euthanasia has the potential to introduce a degree of coercion that would undermine the will to live for certain persons, it follows that the societal benefits referred to will result in the loss of choice for some individuals. In which case, it transpires that the benefits for society can only be judged as benefits by appealing to a utilitarian framework. As previously noted, utilitarianism is properly judged to be the antithesis of the common good because it allows for the rights and well-being of particular individuals to be completely over-ridden by what is deemed good for the majority.

Now it emerges that the new account, biased as it is towards self-interest, is significantly at odds with a robust notion of the common good even while it promotes individual choice and is capable of achieving outcomes that have identifiable tangible benefits for certain groups, possibly even for a majority of people.

At this point a strong case could be made that the traditional account, given its concern for the broader relational and social dimensions of decision making, is more sympathetic than the new account to recovering or upholding the common good. Be that as it may, the more interesting and important matter, I would contend, is the inherent ability of the traditional account to support a robust notion of the common good. Stated negatively, the question is whether, given its bias towards the well-being of the community, the traditional account might not ultimately fail to adequately respect the perspective of individual persons.

\section{MORAL HYPERPLURALISM}

Lisa Sowle Cahill, writing about the challenges of upholding the vision of the common good in our time, corroborates the shift in moral thinking described by McGovern, outlined above. She then describes the need to restore power to the concept of the common good as a "critical issue".

26 There is already substantiated evidence of a direct link between health-care costs and the option for assistedsuicide. In Oregon, for example, a number of persons requesting expensive drugs for life-limiting conditions have been reminded of their right to access state-sponsored suicide in the very same letter in which they have been declined the treatment able to address their condition. See Edward Mahoney "Abused and Exploited"<www.vaeh.org/resources/

Abused $\% 20$ and $\% 20$ Exploited $\% 20$ Case $\% 20-\% 20$ Wagner\%20and $\% 20$ Stroup.pdf $>$. 
Speaking as a Catholic, she writes that we can no longer take for granted that, in practice, it continues to form the foundation of a Catholic social ethics. ${ }^{27}$

Reflecting on the impacts of globalisation on the sources of moral and social authority, Cahill highlights the contemporary antipathy between care for others and self-interest that has resulted from the shift in the locus of moral authority from hierarchical office to the individual person: In contemporary western societies the ${ }^{28}$

age of globalisation has displaced the idealised view of authority as consisting precisely in an office of care for the common good and replaced it with a realistic reading of authority as power propelled by self-interest.

This state of affairs is well described as 'hyperpluralism'.

The term 'moral hyperpluralism' is not readily found in a dictionary of ethics or moral theology or law. If hyperpluralism, generally understood, is the view that participation by too many groups demanding too many resources from a government leads to political paralysis, then I would argue that 'moral hyperpluralism' is a state synonymous with a significant degree of moral/ethical paralysis amongst those in a position to exercise moral leadership; a state of affairs, resulting from the understanding that we are each the arbiters of our own truth and rightfully entitled to demand and realise our own particular wants or desires. In terms of the development of public policy, regulations and laws, moral hyperpluralism reflects a particular starting position; that (moral) decision making is largely a matter of individual choice and freedom and therefore should, as much as possible, be devolved to individuals. The consequence of this is a move away from state controlled regulations or, more accurately, a move to protect individual autonomy as the highest possible value with increasingly fewer exceptions. ${ }^{29}$

This stance is evident in a recent discussion paper published by the Advisory Committee on Assisted Reproductive Technology (ACART) simply titled Ethical Framework for ACART. ${ }^{30}$ There we read: ${ }^{31}$

27 L Cahill "Globalization and the Common Good" in J Coleman and W Ryan (ed) Globalization and Catholic Social Thought: Present Crisis, Future Hope (Orbis Books, New York, 2005) at 45.

28 At 44 .

29 It is acknowledged that there are still a number of areas of law where individual autonomy is clearly limited for the sake of the well-being of others. Laws protecting individuals from discrimination and the Resource Management Act 1991 are two areas that come to mind.

30 It is also acknowledged that the Human Assisted Reproductive Technology Act 2004 (under which ACART is established) is itself an example of State regulation. The point being pursued here, however, is that decisions about the regulation of practices governed by the Act are becoming increasingly subject to the principle of autonomy above all others. The discussion paper by Jones and Whittaker is offered as evidence of this shift. 
To a certain degree, reproductive liberty can be seen as a negative right of non-interference (i.e. no unjustified barriers should be placed in the way of people pursuing their reproductive choices). In other words, the presumption is that activities should only be prohibited if there are pressing reasons to do so.

In articulating the pressing reasons for prohibiting certain activities, the discussion paper rightly tips its hat to the need to take account of the effects on broader society: ${ }^{32}$

These pressing reasons set limits to the pursuit of reproductive choice, and include decisions that may adversely affect broader society, any legal prohibitions and the harm principle.

At the same time, however, in further articulating its understanding of the idea of adverse effects, the discussion paper reveals a clear bias towards protecting from the harm of limiting individual choice. Indeed, the need to limit the autonomy of certain individuals or couples is first of all justified by any adverse impact it might have on the freedom of others: ${ }^{33}$

Perhaps the best formulation is that whilst autonomous decision-making should be supported and encouraged, it is legitimate to limit this autonomy where its exercise unreasonably impacts on the autonomy of others, or threatens others with significant harm.

The fact that the threat of significant harm to persons other than those choosing to use the technology is listed alongside, but following, the harm of limiting autonomy, immediately raises the question of whether it is, morally and ethically speaking, of secondary importance. Closer scrutiny would seem to confirm that this is indeed the case.

In terms of the Human Assisted Reproductive Technology Act 2004, those "others" likely to have "significant harm" visited upon them clearly include, as a priority, women and children. ${ }^{34}$ Now, while the discussion paper in question acknowledges that the Act "specifically instructs that special consideration is given to the welfare of the resulting child and of the women involved," 35 it also immediately qualifies the nature of that special consideration. Thus we read that: ${ }^{36}$

... the interests of the welfare of these parties are not a paramount consideration and can be balanced against the interests of the welfare of other parties, in addition to other ethical values as outlined below.

31 Gareth Jones and Maja Whitaker "Ethical Framework for ACART" (June 2012) Advisory Committee on Assisted Reproductive Technology <acart.health.govt.nz> at 12 (emphasis added).

32 At 11 .

33 At 11 (emphasis added)

34 Human Assisted Reproductive Technology Act 2004, s 4

35 Jones and Whitaker, above $\mathrm{n} 31$ at 11.

36 At 10. 
Further, the bias towards defining 'harm' in terms of the harm that is visited upon individuals when their choices are restricted is revealed by the fact that the quote just referred to is immediately followed by a list of various values, the first of which is autonomy.

In fairness it needs to be noted that included in this list of values is the value of "Social Trust and Responsibility", defined in terms of respect for the relationships between individuals and communities, ensuring equity and encouraging co-operation. ${ }^{37}$ Of particular interest for this discussion is a reference to the common good. Somewhat encouragingly we read: ${ }^{38}$

While an individual's right to autonomous decision-making should be highly valued, it may at times need to be balanced against the potential for harm to other individuals or society at large.

The language, however, is tentative and the above statement is, once again, quickly qualified. Reading on it is stated that while: ${ }^{39}$

[o]n occasions the common good may outweigh individual interests ... such occasions are likely to be exceptional, and even in these exceptional circumstances the interests of the individual should still be protected.

While it is not stated explicitly, the context makes it abundantly clear that by "interests of the individual" is meant above all an individual's right not to have their particular choice interfered with.

The ACART discussion paper highlights a further aspect of the challenge faced in promoting the idea of the common good. Not only is it seen by many as being one value amongst a number of values, and given a lowly weighting at that, considerations of harm to society at large, when they feature, are in large part too-narrowly framed around the loss of non-interference of society or other individuals. This, in turn, means that those who show any sort of willingness to promote the common good as a key value are likely to be working from a very narrow and impoverished understanding of what the notion means.

What is clearly needed is a more adequate account of the potential harms to society, something that is very difficult to achieve, not just because they are, of their very nature, more speculative but also because ethical reflection in our society, dominated as it is by the new morality, naturally tends towards an exaggerated and distorted emphasis on the individual.

37 At 13 .

38 At 13.

39 At 12 (emphasis added). 


\section{THE COMMON GOOD AND MORAL HYPERPLURALISM}

The approach exemplified in the ACART discussion paper, but by no means limited to policy development in this area, poses a real challenge to social order and the common good in societies such as ours. Dennis Wrong puts it like this: ${ }^{40}$

The problem of order is ... rooted in inescapable conflict between the interests and desires of individuals and the requirements of society: to wit, the pacification of violent strife among men [sic] and

the secure establishment of co-operative social relations making possible the pursuit of collective goals.

Talcott Parsons makes an important point that corroborates Wrong's insight when he argues that: ${ }^{41}$

... people have limited capacities to sympathize with their fellow human beings: there is a constant tension between the moral obligations they feel toward other people and the impulse to promote their own interests. What is desirable from a normative perspective does not necessarily correspond to our actual needs, wishes and desires.

Parsons identifies this state of affairs as being rooted in our "moral shortage" - something that, from a theological perspective, we might unpack as relating to our human limitations on the one hand and human (original) sinfulness on the other.

It could be said that Wrong and Parsons are merely stating the obvious. It could also be said that they are saying essentially the same thing. On closer examination, however, there emerges a subtle but important difference. The subtlety being referred to lies in the different adjectives employed. What Wrong labels as an "inescapable conflict", Parsons refers to as a "constant tension". Taking proper account of this difference has the potential to lead to a very different way of approaching and understanding human flourishing, and therefore the common good, in our time.

The term conflict betrays an adversarial posture which quite obviously describes the new morality outlined above; an account in which the considerations of the individual are given moral precedence over the requirements of society - the sort of precedence that I have already suggested undermines certain considerations central to promoting a robust account of the common good. ${ }^{42}$

At the same time, the adversarial notion of conflict is equally relevant for describing various versions of the traditional account of morality in which the requirements of society were often given

40 Quoted in A Komter Social Solidarity and the Gift (Cambridge University Press, Cambridge, 2005) at 102.

41 Quoted in Komter, above n 40, at 102.

42 Here it should be acknowledged again that for those who see the new morality as an important corrective to the traditional accounts of morality, it is not unreasonable to maintain that their account, based as it is on a certain idea of what brings human flourishing, embodies and expresses a particular account of the common good. 
precedence over the flourishing of the individual - often justified in the name of the common good. Stated differently, one might say that the notions of communion and community are only more obvious in (at least some forms of) the traditional account because of an inherent lack of affirmation of the importance of the person and personal choice. In which case it is arguable that (at least some forms of) the traditional morality also undermine/s key considerations central to promoting a robust account of the common good.

This understanding features in various pre-Vatican II Catholic moral publications, including the 1962 Dictionary of Moral Theology which states: "The common good is the good of a society; as such it is superior to the good of the single individual." While the entry states clearly that "the good of society is not to be sacrificed to the good of the individual, nor the good of the individual to society", nevertheless the meaning is clear; the common good exists over and against individual flourishing. ${ }^{43}$

A similar understanding is revealed by Pope Pius XII in an allocution given in 1952. There we read of three principles that need to be invoked for "the moral justification of new processes, new experiments, and methods of research": ${ }^{44}$

(1) the interests of medical science;

(2) the individual interests of the patient under treatment;

(3) the common interests of the community, the bonum commune.

Later in the same address the "bonum commune" is translated as the common good and, while identified as "closely bound up with" the "two sets of interests already named, those of science and those of the patient", it is nevertheless clearly understood as a separate and "third set of interests". ${ }^{45}$ Once again, while challenging those who would subordinate the individual to the community in the name of ethical research (as occurred as a result of the unethical human research carried out during the Second World War), Pius XII portrays the interests of the individual as being in a certain 'conflict' with those of the common good.

This conflict is unfortunate. Whatever criticism we might have of postmodernism, postmodern commentators are right to point out that one of the risks and consequences of traditional approaches to morality is their tendency to ignore individuality and situational complexity by an approach that absorbs difference into sameness. Brian Johnstone, articulating the thought of Jacques Derrida, puts

43 P Palazzini (ed) Dictionary of Moral Theology (2nd ed, Burns \& Oates, London, 1962) at 257 (emphasis added).

44 Pope Pius XII "The Intangibility of the Human Person: Allocution to the First International Congress of Histopathology" in The Monks of Solesmes (ed) The Human Body (St Paul's Editions, Boston, 1952) 353 at 196.

45 At 201 
it well, noting that the traditional metaphysical systems of thought that have developed in the Western philosophical system "prioritize being, substance, sameness and permanence across time or presence." ${ }^{46}$ By imposing "unity on plurality and stasis on change, thus wrapping everything and everyone in a static totality", metaphysical systems of thought exclude the 'other', where the other is represented by marginalized individuals and groups excluded by the presently existing forces of social and political domination. "This exclusion is often characterized as a form of oppression or even of violence" against various individuals. ${ }^{47}$ In the words of Robert Schreiter: "denial of difference can lead to the colonization of a culture and its imagination." 48

Therefore, tempting as it might seem, and even in the face of an exaggerated focus on the rights and autonomy of the individual, the task of recovering/upholding the common good in our time will not be achieved by simply embracing again, or stubbornly holding on to, the traditional account of morality. This is so even if we accept that the traditional account of morality more naturally inclines us to considerations of the needs of others because of its promotion of values such as service and self-sacrifice; values which are undoubtedly essential to any robust concept of the common good.

\section{RECOVERING THE COMMON GOOD AND MOVING BEYOND MORAL HYPERPLURALISM}

If neither the traditional nor new accounts of morality are capable of upholding the common good in the contemporary postmodern society in which we live then we are faced with a prior task; that of formulating an alternative account of morality capable of upholding the values that are congenial to a public sense of the common good.

What will this account look like? It will, in the first instance, be inductive and dialogical. Within this account, pronouncements about the common good will be continually revised rather than being dogmatically announced and pre-emptively enforced. Without accepting the key premise of postmodernism, which, if taken to an extreme, threatens to subsume sameness and essence into difference, what is needed is an approach that is committed to holding in tension what Parsons has termed the "interests and desires of individuals and the requirements of society." 49

That is to say, if our efforts are to succeed, we need to commit ourselves to a particular understanding of the common good - one that does not pit the individual's needs against the good of society but rather sees them as being in a necessary and critical tension. When we speak of

46 B Johnstone "The Ethics of the Gift: According to Aquinas, Derrida and Marion" (2004) Australian eJournal of Theology 3 at 2 .

47 At 2 .

48 Robert Schreiter Humanity before God: Contemporary Faces of Jewish, Christian and Islamic Ethics (Fortress Press, Minneapolis, 2006) at 59.

49 Quoted in Komter, above n 40, at 102. 
recovering the common good we must take care to ensure that persons are seen as both the architects and the beneficiaries of society. The economic, social, political, ethical and legal institutions set up by society must enhance the development of the individual human person, not restrict it, even while they seek to promote the sorts of social conditions that will deliver equality and promote the collective good.

Nevertheless a word of caution is warranted. Given the limited capacities we have to sympathise with our fellow human beings, and given that the dominant account is skewed to individualism, we will have to be particularly vigilant about the way our 'moral shortage' inclines us to forget the impact of our decisions on others.

While a suitable coherent alternative moral account has yet to emerge, the broader and more inclusive understanding being argued for here can be found in various relatively recent articulations of the common good within Catholic Social Teaching. It is, for example, evident in the definition provided by the "Pastoral Constitution on the Church in the Modern World" where it is described as "the sum total of social conditions which allow people, either as groups or as individuals, to reach their fulfilment more fully and more easily." ${ }^{50}$ It is also evident in Pope John Paul II's encyclical Sollicitudo rei socialis where the common good is described as "The good of all and of each individual". ${ }^{51}$ The encyclical Pacem in terris also puts it well when it states that "it is agreed that in our time the common good is chiefly guaranteed when personal rights and duties are maintained." 52 In Cahill's words: ${ }^{53}$

Within the common good, the dignity and rights of the individual and the welfare and cohesiveness of the social body are balanced and seen as interdependent and mutually necessary.

For those who are seriously concerned about the common good, the need to adopt a new account of morality is highlighted by a further reality. Those organisations who readily continue to promote the notion of the common good, being those that generally speaking are tied into what I have described as the traditional account of morality, remain too closely coupled to a particular model of social theory and political organisation; one that, because it is based largely on a top-down, orderly and hierarchical category notion of authority, is today regarded as obsolete and even 'immoral' by many. This creates a significant barrier to advancing the notion of the common good as part of the daily currency of moral transactions in contemporary society.

50 Second Vatican Council, above n 1, at [26] (emphasis added).

51 Pope John Paul II Sollicitudo Rei Socialis: On Social Concerns (Encyclical Letter, 1987) at [38-39].

52 Pope John XXIII Pacem in Terris: On Establishing Universal Peace in Truth, Justice, Charity and Liberty (Encyclical Letter, 1963) at [60].

53 Cahill, above n 27, at 42. 
What is urgently needed is a coherent moral account in which the common good can be seen as existing independently of the hierarchical and orderly structures that permeate the institutions traditionally most concerned about upholding some version of the common good. To fail to do so is to run the risk that attempts to recover the common good will be (mis)interpreted as yet another means by which particular hierarchical institutions, such as the Churches, are simply seeking to maintain the status quo in terms of a particular style of leadership and exercise of authority.

Once again, Cahill, in her typically direct mode of argumentation puts it well:

The continuing vitality of Catholic Social Teaching and the concept of the common good cannot be discovered by employing a model of society or of social theory that works with the old top-down, orderly, and hierarchical categories of social structure and social authority.

These are categories that globalization and other changes to our society have rendered more and more irrelevant. ${ }^{54}$

What might this new moral account look like? It will be based on a theory of human solidarity that begins with an understanding of human persons as essentially interrelated. Above all, it will draw on "the grammar of human relationships" ${ }^{55}$ to coin a phrase used by Vincent Hunt, and all that entails, including the virtues of care, commitment, service and selflessness. It will reflect an approach to solidarity that, in the words of Michael Sandel, rather than settling for some individualistic common denominator or seeking some other thin but shared abstract ideals, is based on an openness to the ways in which the different social and cultural groupings work from within and conceive of respect for persons. ${ }^{56}$

I suggest that it will draw heavily on, if not resemble in its blueprint, the personalism of the young Karol Wojtyla, later to be Pope John Paul II; a personalism that avoids the trap of locating reality in essences rather than subjects and is capable of incorporating the real world of persons. ${ }^{57}$ In this real-world account there will be conceptual room for taking cognisance of the "moral shortage" of persons, another point of clear difference between the traditional and new accounts described above. Finally, I suggest that it will be based on an anthropology that recognises the 'givenness' of life as expounded by various thinkers of the gift, both religious and secular. ${ }^{58}$

54 At 45 .

55 V Hunt "What's in a Christian Name?" (2012) 46 Compass 2.

56 J Roberts "The Tablet Interview: Joined-up Thinker" The Tablet (United Kingdom, 6 March 2010) at 8.

57 T Rowland "A Symphony of Theological Renewal" The Tablet (United Kingdom, 17 November 2012) at 16.

58 Seeing life as a 'given' sits well with a religious worldview in which God is regarded as the originator and giver of all life. However, the notion of 'gift' is also developed by a number of secular philosophers, such as 
A good starting place for such an account can be found in the work of Catholic moral theologian Brian Johnstone. Johnstone postulates that the opposition between the individual and the rest of the world, including other persons, is an innovation that came about as a result of a shift in the way in which the notions of subject and object came to be regarded in western thinking and culture. This shift, which he regards as the "central problem" of western philosophy, was the result of a departure from an earlier "unified vision" of the world (prior to the 14th century) that, in philosophical terms, resulted in the subject and object becoming separated, with the latter being left without any source of value in itself. ${ }^{59}$ The consequence of this separation is described by Johnstone as the move to an account of knowing and willing in which true knowledge and valuation are sought primarily within the subject. From this situation emerged those kinds of moral theory which sought to find guiding structures in the self-subject rather than in essences or in human nature, theories in which sameness is subsumed by difference.

This analysis provides a cogent explanation for the emergence of those moral accounts that fall under the broad classification I have termed the new morality. At the same time, it also explains the emergence of the various traditional accounts of morality. Whereas new morality resolves the perceived opposition between the subject and that which is 'other' in favour of the individual subject, traditional morality resolves the opposition in favour of the object such that the object is typically perceived as an entity prior to, and thus separate from the free choice of the moral subject. In other words, "there is a morality in the object considered separately from the subject." 60 The tendency, then, is for the individual subject to be reduced to a merely passive receiver - difference is subsumed by sameness.

Johnstone concludes that an account based on the givenness of life, ${ }^{61}$ in which the person is defined in the first instance as a receiver and giver, is capable of sustaining both sameness and difference. Both are given their due place without one absorbing the other. ${ }^{62}$ Thus: $^{63}$

The basic structures of ontology, in this view, would rest on a dual subjectivity: the giver is a subject; the receiver is a subject; the object is the relationship of giving and receiving together with the entity which is given.

Michael Sandel, who argue that life is a given for all persons considering that none of us asked to be born or had a say in how or where we were born or our makeup.

59 Johnstone, above n 46, at 7.

60 B Johnstone '"Objectivism', 'Basic Human Goods', and 'Proportionalism', an Interpretation of the Contemporary History of Moral Theology" (2005) 43 Studia Moralia 1 at 105.

61 See Hunt, above n 55.

62 B Johnstone "The Gift: Derrida, Marion and Moral Theology" (2004) 42 Studia Moralia 2 at 418.

63 Johnstone, above n 46, at 5. 
Now it is no longer a matter of seeking meaning in the subject or in the object. An approach drawing on an anthropology based on gift seeks meaning in the relationship between two subjects.

The work of Johnstone and other thinkers of the gift provides a positive way forward for achieving a new and vital consensus about the common good; one which, because of its emphasis on the relationship between the individual subject and that which is other, the collective well-being which is also regarded as subject, is likely to lead to a genuine recovery of the common good; one in which, recalling again the words of Pope John Paul II, the good of all and of each individual can be upheld and promoted; one in which the individual's needs can genuinely be regarded as existing in a critical tension with the collective good rather than being defined in opposition to it.

\section{CONCLUSION}

It has been argued that a robust commitment to the common good requires recognising and embracing the inescapable tension between our own personal interests and our sense of obligation to the welfare of others. It is relatively obvious that the new account of morality, as defined in this article, fails to do this. At the same time, it has been argued that the traditional account, because of the tendency to pit the good of society against the individual, also fails to adequately uphold the tension that defines a robust understanding the common good - this despite its strong commitment to the inherent sociality of persons. Therefore, if we are truly serious about recovering and promoting the common good, we need a new moral account, one capable of holding in creative tension both the interests and desires of individuals and society as a whole.

Those of us who belong to institutions with heavy investment in the traditional account cannot ignore the importance of individual freedom and choice when considering the common good of society. The correction that is sorely needed in our time in order to recover and/or uphold the common good will not be achieved by way of a moral arm-wrestle that simply attempts, once again, to shift the balance of power between individuals and the so-called common good. Rather than continuing the arm-wrestle we need to initiate a handshake. Accordingly, it has been suggested that the basis for articulating a robust account of the common good may be found in the foundational and innovative work being done by thinkers of the gift, such as Brian Johnstone, to establish an alternative account of morality.

It has also been illustrated, by way of a brief analysis of the thinking behind the regulation of assisted reproductive technologies, that public policy in New Zealand reveals a state of 'moral hyperpluralism' which leads to an inadequate and impoverished concept of 'harm'. If we are to avoid a situation where future debates about critical ethical matters (such as the legalising or continued prohibition of euthanasia and assisted-suicide) will also be shaped in a milieu defined by moral hyperpluralism, then the work of recovering the common good should be seen as an urgent task. 
